\title{
INSIGHTS INTO STRUCTURALLY IDENTICAL EXPERIENCES OF RESIDENTIAL CARE ALUMNI: THE PARADOX OF BECOMING AUTONOMOUS IN A RESIDENTIAL CARE FACILITY
}

\begin{abstract}
Andrea Nagy
Abstract: In this study, which is part of my $\mathrm{PhD}$ thesis project, I used the documentary method of interpretation to analyze a discourse on the prospect of leaving care and living autonomously that emerged from group discussions among youth living in a residential setting in Alto Adige [South Tyrol], Italy. The documentary method of interpretation not only examines the explicitly expressed contents of the discourse, but also reconstructs the young person's implicit, or atheoretical, knowledge underlying and orienting habitualized social action. The method focuses on group-based social patterns that, when applied in care-leaver research, give valuable insights into structurally identical experiences young people in institutions of residential care share that concern the normative educational goal and expected learning outcome of autonomy. The analysis of the group discussions suggests that becoming autonomous in a residential institution is, from the perspective of the young people, a paradoxical arrangement with compulsory character, and that they have developed group-specific patterns and strategies to manage it. This article will present those social patterns and strategies. An understanding of the influence of the paradox is necessary if we are to improve outcomes of the social pedagogical treatment model in residential care settings and thus improve the life chances of residential care alumni and the experience of leaving care for young adults.
\end{abstract}

Keywords: residential care, residential care alumni, care leaver, transition to adulthood, autonomy, experiences of residential care alumni

Andrea Nagy PhD is a full-time lecturer and Course Leader of Social Pedagogy in the Department of Social Sciences, University of Applied Sciences, Matthias Corvinus-Straße15, A-3100 St. Pölten, Austria. Email: Andrea.Nagy@fhstp.ac.at 
International Journal of Child, Youth and Family Studies (2018) 9(2): 61-85

Young people who have received long-term group care in residential homes have significant difficulties in taking steps toward autonomous living, steps they must take earlier in life - and thus with less preparation - than youth living in mainstream families, even though insufficient preparation has been proven to be detrimental to care leavers' future possibilities. Stein (2006) offered some reasons:

They are more likely than young people who have not been in care to have poorer educational qualifications, lower levels of participation in post-16 education, be young parents, be homeless and have higher levels of unemployment, offending behaviour and mental health problems (p. 273).

Tänzler \& Luckner (2012), who investigated "nine lives after [residential youth] care", concurred that some factors are likely to cause social exclusion after care:

low or missing qualifications after compulsory education, lack of integration into the first job market, poverty, problems finding housing and jobs, particularly among ethnic minorities, bad health care services and a high risk for delinquency ${ }^{1}$ (p. 139).

Some current international literature on care-leaving concentrates on the policies and legal frameworks of various countries, including European ones (e.g., Barbarotto \& Mineo, 2012; Lerch \& Stein, 2010; Munro, Stein, \& Ward, 2005; Stein \& Munro, 2008). In several countries, those studies revealed a lack of statistical data about care leavers and their processes of leaving care, which hampers the establishment of a broad research base for the issue. There is little research focused on group residential facilities in general and a lack of evidence-based research on outcomes for youth placed in such settings.

As South Tyrol has a substantial German-speaking majority, many schools are Germanspeaking, and a strong connection is maintained to German culture. Because the German tradition of social pedagogy is upheld in professional work there, the German literature is relevant to the current study. In Germany the five best-known studies on effects of residential care are Planungsgruppe Petra (1988), the so-called JULE study (Baur, Finkel, Hamberger, Kühn, \& Thiersch, 1998), the Jugendhilfe-Effekte-Studie [Youth Welfare Effects Study], called JES (Bundesministerium für Familie, Senioren, Frauen und Jugend, 2002), the Evaluation erzieherischer Hilfen [Evaluation of educational aids] called EVAS (Macsenaere \& Knab, 2004) and the Bundesmodellprogramm wirkungsorientierte Jugendhilfe [Federal model program impactoriented youth welfare] (Albus et al., 2010). The mentioned studies have a wide range of methodological approaches and are of varying scope. In the studies where care leavers are actually interviewed, their individual retrospective views on the residential care setting are the main focus. This is also true for international care leaver studies, and for the majority of the 33 empirical studies

\footnotetext{
${ }^{1}$ All translations from German are my own
} 
International Journal of Child, Youth and Family Studies (2018) 9(2): 61-85

in various (mostly European) countries that are discussed by Harder, Köngeter, Zeller, Knorth, and Knot-Dickscheit (2011), who described — for the first time systematically — the methodological approaches that have been used in care-leaver research. The selection of the studies was not itself based on systematic research, but was informed by the International Research Network on Transitions to Adulthood from Care at Loughborough University. Harder et al. (2011) warn of the difficulty of making valid causal inferences in such studies:

Since many studies on transition from care into adulthood include only one sample of young people and relatively small sample sizes, it is difficult to draw causal inferences between the care that is being offered and the outcomes that are achieved. (p. 2439)

Furthermore, there is insufficient literature about the characteristics of the various settings, services, and youth served.

\section{The Social Pedagogy Model and Autonomy as an Educational Goal}

Group care practice in many European countries employs the social pedagogy model, which provides a "methodology based on an intervention project with pedagogical planning and involves well-grounded goals, working models, activities, and techniques" (del Valle, 2014, p. 2955). In contrast to some English-speaking countries, where those working in residential care programs often have no specific qualifications (del Valle, 2014, p. 2955), Alto Adige [South Tyrol], Italy, where the investigation took place, provides a university degree and "qualification in social pedagogy ..., which equips its holders to work with dependent populations, notably those in child residential care" (del Valle, 2014, p. 2955). In the Italian language the qualification is named educatore sociale [social educator]. In the social pedagogy model of preparation of future care leavers, autonomy is a normative educational goal, one that encompasses life-skills, decisionmaking competencies, responsible social behaviour, and more. As Wolf (2002) phrased it:

Autonomy is a central objective of education ... education which fails to ensure that children reach autonomy, is not successful. ... Particularly in residential group care the question of 'how children reach autonomy?' is a precarious question. Considering educational plans (helping plans) which are directed to youth, transition to autonomy emerges everywhere. (p. 9)

In the present study young people in residential care were asked about autonomy and their lives after care.

Contrary to the institutional expectation that young people in residential care institutions will undergo a smooth process of competence acquisition towards the desired objective of 
International Journal of Child, Youth and Family Studies (2018) 9(2): 61-85

autonomy, a structurally identical experience ${ }^{2}$ among young people in institutions of residential care is that becoming autonomous in a residential institution is a paradoxical arrangement with compulsory character. In order to manage it they have developed the group-specific sprachliche Handlungsmuster [patterns of communicative action] portrayed in this study.

\section{Method}

As elaborated earlier, pathways of youth leaving care (both foster care and residential care) are usually investigated on an individual biographical level from a retrospective perspective. This qualitative study presents a different research approach, one that looks ahead to the impending transition from care, and focuses on the group rather than the individual level. The aim of the investigation has been to analyze specific and significant group discourse and to utilize the knowledge gained to enhance the effectiveness of group care practice in relation to the preparation of young adults for leaving care. The research is based on an analysis of group discussions with three groups of young care leavers (20 young people, aged 12 to 19 years) in a residential setting in South Tyrol. The young people were asked to discuss amongst themselves their prospects with regard to leaving the care setting and living autonomously. Six group-specific patterns of communicative action emerged as an answer to the paradoxical situation they were in regarding the educational objective of autonomy. The data were analyzed using the documentary method of interpretation (Bohnsack, 2014, p. 222), which allows not only interpretation of the explicitly expressed contents, but also the reconstruction of the young person's implicit or atheoretical knowledge, which underlies and orients habitualized social action.

The formal frame of communication in group discussions (which always takes the form of passages from the initiation to the conclusion of a topic) offers a relatively constant framework in which to distinguish particular implicit meanings or rules among a group through a sequence analysis of the transcribed text of the group discussion. There are two consecutive steps in the analysis: the formulating interpretation, which reveals the topical structure of the text by asking what was said in a communicative manner; and the reflecting interpretation, which reveals with which structure the topic is dealing. Bohnsack (2014) explained that an utterance

is determined by the reaction of the other participants, respectively, by a sequence of reaction and re-reactions; the interpretation of the relation between an (empirically observed) utterance andan (empirically observed) reaction opens up access to the constituted implicit meaning or the implicit rule (p. 223).

\footnotetext{
${ }^{2}$ Bohnsack explains that structurally identical experiences result from "being involved in a specific every day practice" (Bohnsack, 2014, p. 222), such as the residental care setting. His term for such a milieu is a "conjunctive space of experience", which can be traced in a sequential analysis of the linguistic expressions in group discussions. This study detected few structurally identical experiences in the group of young people living in the residential group home. In fact, only one was identified among the 20 participants: the paradoxical arrangement with compulsory character in relation to the normative educational objective of autonomy.
} 
He also noted that:

Individuals sharing a common a-theoretical knowledge and experiences, and thus a habitus, are connected by the elementary form of sociality, which we call "conjunctive knowledge" or "conjunctive experience" [ to be distinguished from the communicative level of interaction]. They understand each other immediately. (pp. 221-222)

In the analysis this emerges in the form of homologous reactions (Bohnsack, 2014, p. 224) in a case-internal comparative analysis (Bohnsack, 2014, p. 228). Questions answered in this step of the analysis are: What kinds of orientation can be traced? What is the group's mindset in reference to each topic? Through comparative analysis between cases (each discussion constitutes one case) it is possible to analyze how the different groups perform differently in relation to the same topics. A common frame of orientation that has been arrived at by comparing different cases is called a type. The sociogenetic typification eventually tries to answer the question of what is typical about the orientation or habitus.

In conducting group discussions the aim is to create an almost natural conversation among the group members so that they can develop their own discourse organization, which can be reconstructed afterwards. The moderator has to formulate the initial question vaguely enough to prevent a proposition, which would necessarily impose a predetermined orientation upon the group. In the case of the group discussions in this study, the question on autonomy amounted to a proposition because autonomy is a normative learning objective in the participants' institutional context. That, among other factors ${ }^{3}$, meant that the group discussions effectively became a reenactment of the care setting and the transcribed text became mainly a source for reconstructing how the groups deal with the hierarchical structure of the setting and with definitions of autonomy as imposed through the institutional authorities. The groups used different patterns of communicative action, as defined by Ehlich and Rehbein (1979):

Patterns of communicative action are forms of standardized options of actions, which are actualized and realized in concrete actions. The actors realize their ends in their actions. The single patterns form a potential for the realization of ends, they are utilized by actors in their actions. Each pattern is related to a specific end of potential actors and is structured through this end. This relation can also be briefly termed like this: the pattern has its end; it is functionally oriented toward that end. (p. 250)

\footnotetext{
${ }^{3} \mathrm{I}$, as one of the moderators of the group discussion, had been a former educator of the participants in one of the three groups, and the setting of the group discussion did not obscure the institutional setting. Even though participation in the discussion was voluntary and informed consent was given, it took place in the institution where most of the young people are non voluntary clients. This paper is based on my thesis research, which was admitted by the Doctoral Advisor and Advisory Committee at the University of Innsbruck, which included an ethical check and approval of the project.
} 
Patterns of communicative action are collective in nature: they are not developed through individual action. The patterns refer to ends that are not arbitrary, but have been developed in specific contexts, like that of group care in the residential home with its specific demands. In the discussions multiple levels overlap; these are separated out in the analysis. There is the level of the orientation frame of the institution, which was imposed upon the group in the beginning of the discussion, and which they have to wade through until they are able to develop their own points of relevance in the discourse. There is also the level of the orientation frame of the young people themselves, which is defined by affirmation of and resistance to the orientation of the institution.

\section{Participants in Group Discussions}

There were 20 participants in the group discussions, in three natural groups of six, eight, and six youth who lived together in the care setting as flatmates. Table 1 shows who took part in which group discussion, and how the groups are constituted.

Table 1 Participants in Group Discussions

\begin{tabular}{|c|c|c|c|c|}
\hline Participant & Age & Birth Place & School or Job & Discussion Group \\
\hline Lm & 16 & Venezuela & Vocational school & \multirow{6}{*}{$\begin{array}{l}\text { "XMAS" } \\
-16 \text { to } 18 \text { years } \\
\text { - } 4 \text { male, } 2 \text { female } \\
-50 \% \text { from local background } \\
\quad \text { (according to birthplace) } \\
\text { - } 1 \text { unaccompanied minor refugee }\end{array}$} \\
\hline $\mathbf{K m} *$ & 17 & Morocco & Apprenticeship & \\
\hline Ym & 18 & South Tyrol ${ }^{\mathrm{a}}$ & Vocational school & \\
\hline $\mathbf{C m}$ & 17 & South Tyrol & Vocational school & \\
\hline Tf & 17 & South Tyrol & High school & \\
\hline Ef & 18 & Kosovo & Apprenticeship & \\
\hline Am* & 18 & Afghanistan & Waiter & \multirow{8}{*}{$\begin{array}{l}\text { "OSTERN" } \\
\text { - } 14 \text { to } 18 \text { years } \\
\text { - } 2 \text { male, } 6 \text { female } \\
\text { - } 63 \% \text { from local background } \\
\text { (according to birthplace) } \\
\text { - } 1 \text { unaccompanied minor refugee }\end{array}$} \\
\hline $\mathrm{ANm}$ & 18 & Germany & Internship & \\
\hline Mf & 17 & South Tyrol & Apprenticeship & \\
\hline $\mathbf{J f}$ & 18 & South Tyrol & High school & \\
\hline STf & 14 & South Tyrol & Vocational school & \\
\hline Pf & 15 & Brazil & Internship & \\
\hline Kf & 14 & South Tyrol & Junior high school & \\
\hline Vf & 16 & South Tyrol & Internship & \\
\hline Gm & 19 & South Tyrol & Housekeeper assistant & \multirow{6}{*}{$\begin{array}{l}\text { "SILVESTER" } \\
\text { - } 12 \text { to } 19 \text { years } \\
\text { - } 4 \text { male, } 2 \text { female } \\
-83 \% \text { from local background } \\
\quad \text { (according to birthplace) }\end{array}$} \\
\hline Dm & 18 & Russia $^{b}$ & Vocational school & \\
\hline Om & 12 & South Tyrol & Junior high school & \\
\hline Cf & 14 & South Tyrol & Vocational school & \\
\hline Af & 16 & South Tyrol & Junior high school & \\
\hline $\mathbf{N m}$ & 13 & South Tyrol & Junior high school & \\
\hline Totals & \multicolumn{4}{|c|}{$\begin{array}{l}10 \text { male youth }(50 \%) \\
10 \text { female youth }(50 \%) \\
13 \text { youth born in South Tyrol }(65 \%) \text { and } 7 \text { in other countries }(35 \%)-5 \text { male and } 2 \text { female } \\
2 \text { male unaccompanied minor refugees }(10 \%)\end{array}$} \\
\hline
\end{tabular}

Note. Each participant is identified by an abbrevation (upper-case character) and gender (lower case character $\mathrm{m}$ or $\mathrm{f}$ ). aSecond generation immigrant; parents from Morocco and Tunisia. ${ }^{\mathrm{b}}$ Adopted as a baby by South Tyrolean parents and grew up in South Tyrol. *Unaccompanied minor refugee. 
International Journal of Child, Youth and Family Studies (2018) 9(2): 61-85

\section{Recurring Patterns of Communicative Action in the XMAS Group}

What was expressed during the discussions represents primarily the explicit content, which is - according to the documentary method of interpretation - analyzed through the first step of the formulating interpretation. In this step the communicative contents are explored. Through the subsequent reflecting interpretation the meaning of an utterance is explored in relation to the group context in which it was expressed. If, for example, an utterance was validated by the group or there is a shared conclusion to a sequence, there is shared meaning. Metaphors or other utterances with conjunctive knowledge relate to specific everyday life contexts in which specific shared experiences have been developed. One shared experience across all three groups is the paradoxical demand of becoming autonomous in the institution. Young people find themselves in a situation where they both ought to - and want to - be autonomous. If they act autonomously and as selfsufficient individuals and resist demands to become autonomous, they are thereby perceived as not self-sufficient. If they accede to demands to become autonomous, they are regarded as selfsufficient but are actually directed by others. There is no escape from this paradox, and the impression of being processed through the institution was enacted strikingly by the XMAS group: their drainpipe noise served as a metaphor for their situation. Communicative action patterns of irony and self-debasement as well as self-aggrandizement were preferentially used by the XMAS group in order to manage the imposed framework. These patterns were employed through the reenactment of the care setting and the corresponding relationships between educators and youth through the question of autonomy. An imposed framework is a power-based discourse that can be traced in the analysis with the documentary method of interpretation (Fremdrahmung, as cited by Bohnsack, 2003, p. 234).

At the beginning of the group discussion with XMAS in lines 1 to 5, Km identified himself as the second "Karin", an allusion to a young woman with a learning disability who had left the group. Her ability to live autonomously was seen as limited. The reduced degree of autonomy that Karin had acquired, as perceived by the group, was used in this utterance as a standard for general success in the acquisition of autonomy, which was recognized as a major objective of educational processes in the institution. The irony of that utterance was understood by everyone in the group and validated through laughter.

$\begin{array}{lll}1 & \text { Moderator: } & \text { so, I would like to invite you now to the group discussion on the issue of } \\ 2 & & \text { becoming autonomous in the group or, um, being autonomous. } \\ 3 & \text { various participants: } & \mathrm{L}((\text { whispering during that sentence)) } \\ 4 & \mathrm{Km}: & \text { I am the second Karin } \\ 5 & \text { Tf and various participants: } \quad \mathrm{L}((\text { laughs }))^{4}\end{array}$

\footnotetext{
${ }^{4}$ Transcriptions in this article were created according to the guidelines for transcription in the documentary method of interpretation as outlined in Nohl (2017, p. 123). Lower case is used throughout including at the beginning of sentences. L indicates an interjection. A parenthesized dot (.) indicates a pause for one second; a parenthesized number denotes a pause for multiple seconds. Text surrounded by at-signs indicates an exclamation with laughter (e.g., @yes@). Unclear speech is denoted by ( ), while doubled parentheses indicate remarks by the transcriber.
} 
International Journal of Child, Youth and Family Studies (2018) 9(2): 61-85

The joke is based on conjunctive understanding as a result of shared insider information and as a result of being involved in a specific everyday context inside the institution. Km's indication that he would be the second Karin, implied that autonomous young people are produced in the institution as on an assembly line. He would be the second one off the assembly line in that logic, and the implication was that the production of autonomy functions suboptimally, or with little success.

In lines 13 to $17, \mathrm{Km}$ added another ironical statement in reaction to the moderator's statement that a lot of young people had already left the group in order to live autonomously. His answer carried the connotation that those remaining were leftovers, which functioned as an ironic self-debasement:

13 Moderator:

14

15-17 Km: and all of you, especially when you have been here for longer have seen people coming and going, your colleagues left

$L$ we are the only ones remaining.

In lines 21 to 24 , a metaphor for the group residential home - a drainpipe noise - was validated by all participants through laughter. The metaphor viewed life in the group home as a downward spiral, an undertow that led inevitably down. This descent could be associated with a social decline, or just the feeling of being processed and spat out. The comment "this is the [name of residential home]" was validated with laughter by all participants. The laughter and the comment occurred at the same time. It is both irony and a self-debasement of their group residential home, and their shared life world.

\begin{tabular}{|c|c|c|}
\hline 21 & $\mathrm{Km}:$ & listen! \\
\hline 22 & & ((drainpipe noise in the background $))$ \\
\hline 23 & various participants: & ((laughs)) \\
\hline 24 & $\mathrm{Km}:$ & $L$ this is the [name of residential home] \\
\hline
\end{tabular}

Later in the discussion, in a passage considering what life would be like if there were no rules (lines 618-639), the XMAS group played with the picture of "ending up under the bridge", which emerged as a shared negative orientation or image connected to care-leaving in all three group discussions. In a passage self-initiated by the group, where they considered living together "like in a normal shared flat", they developed an idea about what would happen if they lived together not in a residential home, but in a shared flat without any educators around. They fantasized fighting over something, ending with the picture of each one walking alone onto his or her bridge. The stigmatizing image that young care leavers would end up under the bridge is here taken on and changed in its meaning. If they had a struggle each of them would not end up under the bridge but would "walk onto his bridge". Self-determined and active walking was portrayed,

Bold indicates a loud voice; text enclosed with ${ }^{\circ}$ indicates use of a lower voice; and underlined text was spoken with a higher intonation. Punctuation at the end of an utterance also indicates intonation: lowered (period), raised a little (comma), or raised a bit more (question mark). An elongated syllable is indicated by ::: within the word. 
instead of a passive ending up, and it is one's own bridge that one walks onto, not under, but still all alone, and at one's own behest. The stigmatizing attribution of society towards youth leaving care is at the same time both exaggerated and reinterpreted in that talk. To walk onto one's bridge is like an act of heroism: the participants have played with a stigmatizing image and transformed it. $^{5}$

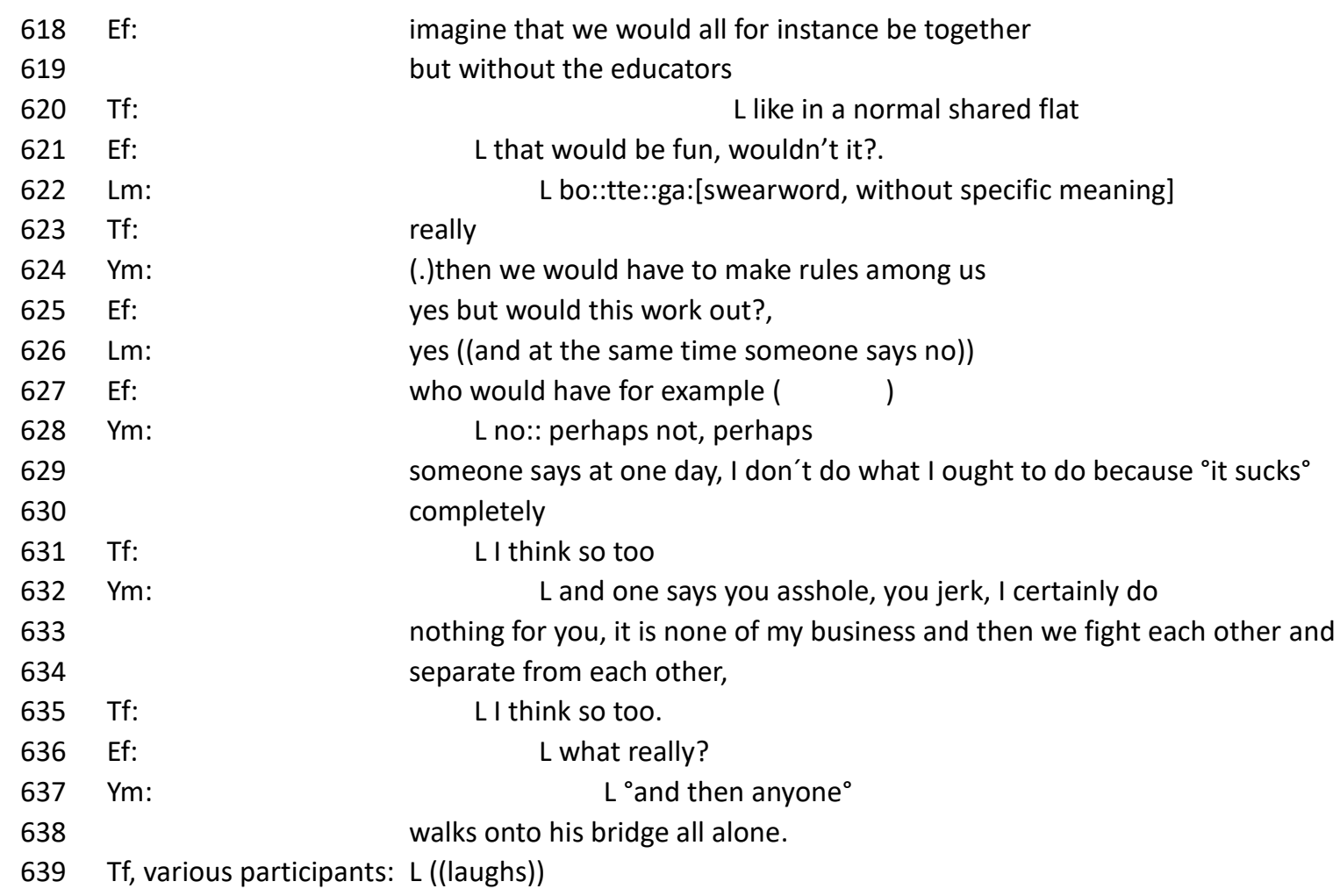

In the last passage, "drug-death fantasy" (lines 2214-2253), the XMAS group developed a heroic end-time scenario. One participant performed a drug-death fantasy, obsessed with his own effect and reducing everyone else to passive spectators. There were no more relationships among the group but only roles and the reflections of the hero on himself. The scenario "our drug party", was constantly questioned by one participant, but they were all given roles by Ym, the main actor in his scenario. Many participants imagined the scenario but in the end only Ym "really wants to end like this", while the other participants distanced themselves from that, or questioned Ym and "never want to end up like this", or commented with "oh God", or "oh green".

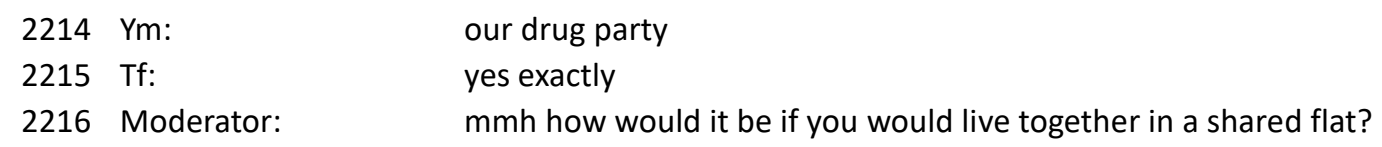

\footnotetext{
${ }^{5}$ In German, to "land under the bridge" is an expression used in the passive voice to describe the inception of homelessness, implying that homeless individuals are themselves to blame for their situation. The young speaker changes this expression to "walks onto his bridge", an active, self-reliant role. He decides where he is going and there is no consideration of guilt or shame.
} 
International Journal of Child, Youth and Family Studies (2018) 9(2): 61-85

\begin{tabular}{|c|c|c|}
\hline 2217 & Ym: & $L$ if you come in the floor would already be sticky \\
\hline 2218 & Tf: & L we all together? I would move out \\
\hline 2219 & Ym: & L smoke. imperial cocaine \\
\hline 2220 & Ef: & $\mathrm{Lmmmh}$ \\
\hline 2221 & Lm: & yeah when you two are together \\
\hline 2222 & Ym: & the floor full of cocaine, no furniture with a syringe pinned \\
\hline 2223 & Tf: & very autonomous [Ym's Name] very cool! \\
\hline 2224 & Ym: & certainly that's how I, how we end up when we are together in a flat. \\
\hline 2225 & Lm: & L whore \\
\hline 2226 & Ym: & bottles everywhere \\
\hline 2227 & Tf: & before I asked you if you would end up like this and you said no. \\
\hline 2228 & Lm: & I can imagine already where it would be \\
\hline 2229 & Ym: & L for sure God \\
\hline 2230 & Ym: & full bottles, everywhere cigarettes on the floor, no furniture any more \\
\hline 2231 & ?: & blood \\
\hline 2232 & Ym: & we have sold everything \\
\hline 2233 & Ef: & $(1)$ \\
\hline 2234 & & ((laughs)) \\
\hline 2235 & Ym: & sold everything to buy drugs \\
\hline 2236 & Km: & this was all \\
\hline 2237 & Ef: & before the girls take him ( ) \\
\hline 2238 & Ym: & $L$ and to mainline \\
\hline 2239 & Lm: & $(1)$ \\
\hline 2240 & Ym: & the girl friend is tattooed and pierced everywhere, that's the girl friend. \\
\hline 2241 & & ((laughs)) \\
\hline 2242 & Tf: & you find her like that \\
\hline 2243 & Ef: & I can imagine you being there \\
\hline 2244 & Tf: & am I fitting in well? \\
\hline 2245 & Ef: & yeah I think he fits in well as well \\
\hline 2246 & Ym: & you have to see my bed with the syringe and Kiss next to it ( ) \\
\hline 2247 & Tf: & that's how you want to end up? \\
\hline 2248 & Ym: & yes \\
\hline 2249 & Tf: & very autonomous, before you did say something different \\
\hline 2250 & Lm: & oh you never \\
\hline 2251 & Ym: & that's how I really wanna end up, that's cool \\
\hline 2252 & Tf: & oh my God \\
\hline 2253 & Km: & oh green \\
\hline
\end{tabular}

\section{Recurring Patterns of Communicative Action in the OSTERN Group}

Whereas the XMAS group used irony and self-debasement as well as self-aggrandizement in their communicative action concerning imposed framework conditions, the OSTERN group utilized very different patterns of communication, namely the neutralizing of an uncomfortable topic through fantasy and positive thinking. Examples of the usage of these types of communicative action are shown below.

Lines 428 to 440 display the positive thinking pattern used by the OSTERN group. A negative (uncomfortable) topic was introduced, which seemed to have a disturbing emotional 
effect on some of the participants. The uncomfortable topic was immediately circumvented using the comment, "Now we should speak about [Kf's name] fingernails." (line 435).

This comment followed a discussion (beginning in line 379) about a young man, a previous member of the OSTERN group whom many knew. A group member told the group that this young man did not earn enough money to afford his own room or flat. He then spent the night wherever he could, began drinking excessively, and eventually became homeless. This story was then associated with a perceived concurrent social crisis in Italy that was understood to make it very difficult to afford housing even when employed. The story prompted other exchanges: first, regarding the danger of drinking excessively; and second, regarding the fact that care-takers are no longer concerned about care leavers after they have moved out of the institution. The discussion was rapidly concluded with the comment, "Hey, come on - look what you have got us talking about!", "Let's talk about [Kf's name] fingernails", at which point the disturbing topic was laid to rest.

\begin{tabular}{|c|c|c|}
\hline 409 & Am: & I'm telling you this because he, because he said that he was happy when he \\
\hline 410 & & was living here, because all the care-givers helped him. they told him that they \\
\hline 411 & & could perhaps him find a place to stay. but since the day he moved out they \\
\hline 412 & & forgot all about him. where is he staying? what is he doing? \\
\hline 413 & Vf: & he hasn't died, has he? ((laughs)) \\
\hline 414 & Am: & no he hasn't died, but \\
\hline 415 & STf: & but I see him sometimes on the street at night (.) drinking beer. \\
\hline 416 & Group: & $(2)$ \\
\hline 417 & Am: & that's not good. when you have problems, beer won't help you solve them. \\
\hline 418 & & you know? \\
\hline 419 & & $(2)$ \\
\hline 420 & Vf: & yes [Am's name], that's true \\
\hline 421 & STf: & yes [Am's Name], that's true \\
\hline 422 & Kf: & L yes \\
\hline 423 & Vf: & yeah really \\
\hline 424 & Kf: & $L$ yes that's true \\
\hline 425 & Am: & but if ((laughs)) \\
\hline 426 & Vf: & it doesn't seem as if you're doing much... \\
\hline 427 & STf: & that's right, we're having a crisis, [Am's Name] \\
\hline 428 & Am: & L no, I don't. and I don't drink either, cause... \\
\hline 429 & STf: & $L$ that's why we've got the beer. \\
\hline 430 & Vf: & ((laughs)) \\
\hline 431 & Am: & hey, come on - look what you have got us talking about! (laughs) \\
\hline 432 & STf: & L it's what you have to talk about every night \\
\hline 433 & Mf: & ( now everybody's awake ) ((laughs)) \\
\hline 434 & Group: & (7) ((laughs and groaning)) \\
\hline 435 & Vf: & and now let's talk about [Kf's name] fingernails. I think in order to be able \\
\hline 436 & & to wear fingernails you'll need - ((laughs)) \\
\hline
\end{tabular}

There was also an effort made in lines 638 to 651 to change the subject of the discussion. The question arose: "Which is more important for autonomy — freedom and money, or 
employment?" The topic was apparently found uninteresting, for it was not willingly discussed, raising comments like, "Let us be!" and "Leave us alone!" More interesting topics included the television series Supernatural, sexuality, and a particular care-giver, whose conduct often seemed to be an issue.

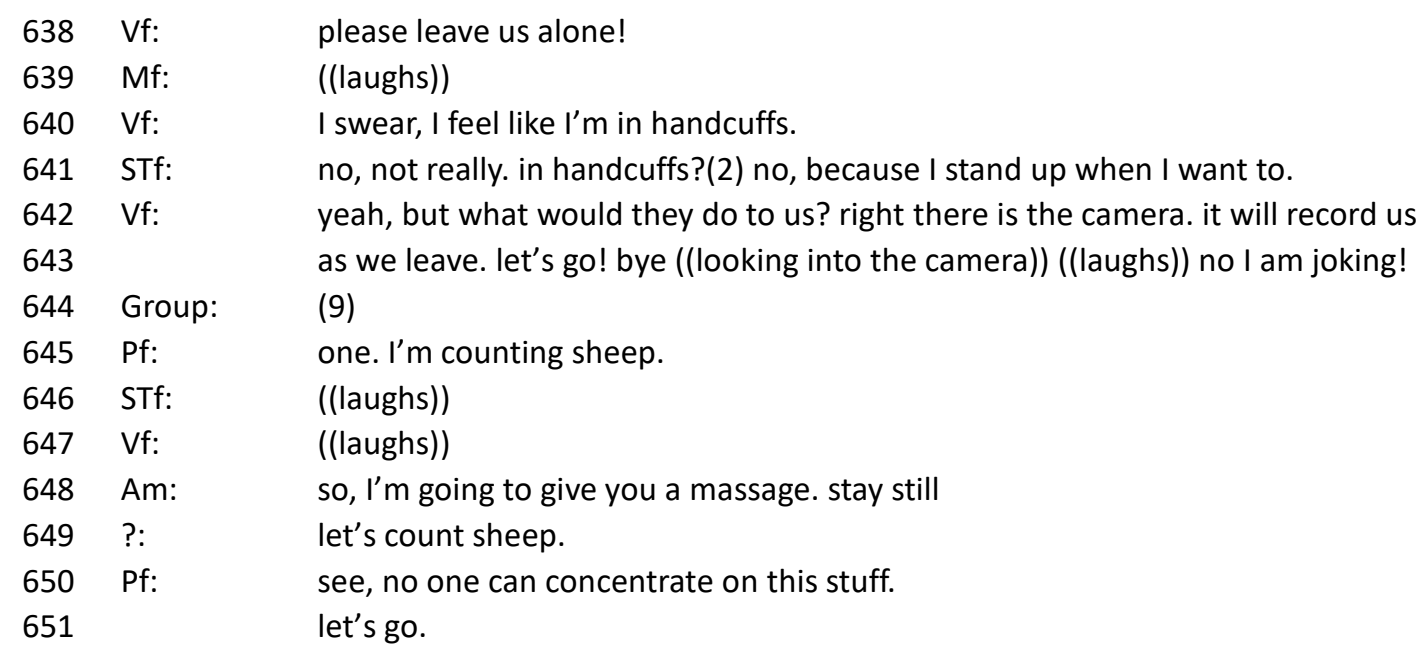

A crisis was the topic of conversation in lines 227 to 253, which included a discussion of whether to buy a house "with a hundred men". This drifting off into fantasy is seen repeatedly in the OSTERN group, and can be psychoanalytically interpreted as a group-based equivalent of a defence mechanism, which in this case would serve the function of protecting the ego.

Defence mechanisms are defined in psychoanalysis as mechanisms in which information can be processed unconsciously so as not to upset the delicate psychological balance. This balancing helps to reduce anxiety arising from stimuli, such as fear, shame or guilt. (Wenninger, 2000)

Laplanche and Pontalis (1999) define the term defence mechanism in their Vocabulary of Psychoanalysis as

all of the mechanisms dedicated to the limitation and/or suppression of any and all modifications which could endanger the integrity and steadfastness of the biopsychological individual. If the ego is an entity which strives to achieve and maintain this continuity, it can function as both an active and a passive factor in these mechanisms. Generally, defence mechanisms should guard against inner irritation/anxiety, possibly resulting in a situation which is contrary to the ego's inner balance and therefore harmful. (p. 24)

The usage of the term defence mechanism has evolved over time, expanding the original concept to include a range of similar meanings. Tolerance of ambiguity and defence mechanisms are seen by Lothar Krappmann (2005, p. 133) as building one of the four categories of identity-promoting 
capabilities $^{6}$. Krappmann's predominantly sociological perspective is not derived from the rigid psychoanalytical definition of identity development based upon step-by-step psychosexual development. His concept of identity implicates a dynamic process of "continuous establishment of balance between the norms and expectations required of each social individual, and the personal needs of the individual which are outwardly projected in order to limit or reject these social stipulations" (Krappmann, 2005, p. 68). The objective of this process-oriented identity is the capability of experiencing the integrity of the self, and the self's integration in the outside world. The definition of "defence mechanism" used in this study is derived from this concept. The situation in which a group discusses a topic that is first, not interesting for the group members, and second, imposed upon them by (perceived) institutional representatives, could trigger a defence mechanism. Various forms of individual defence mechanism have been observed and described in the literature using both the psychoanalytical and Krappman's (2005) perspectives.

The following presents a similar event of shared communications within the group. Analogous to the defending and protecting of a personal individual identity that are required in certain circumstances, Tajfel and Turner (1986) theorized that a shared group identity or social identity may also be shielded and secured. The OSTERN group's preferred pattern of action can be described as drifting off into fantasy ${ }^{7}$; it can be interpreted as a group-based active competence that strives to achieve a balance between the imposed expectations of the institution (taking part in a group discussion) and the group's desire not to participate.

$\begin{array}{lll}227 & \text { Am: } & \text { yes, because in Italy it's too expensive. there aren't any jobs. and when there } \\ 228 & & \text { is some job, they don't pay you enough. if you earn one thousand euros it's not enough to live } \\ 229 & \text { Vf: } & \text { L yes and there are lots of people who } \\ 230 & & \text { give up trying and just stay home. } \\ 231 & \text { Am: } & \text { L yeah but I know lots of people who really work } \\ 232 & & \text { and just can't make ends meet. one guy who earns one thousand euro - what can he do } \\ 233 & & \text { with one thousand? his rent is eight hundred, plus gas, plus expenses, plus clothes. and that's } \\ 234 & & \text { why he has to live with his family, even though he doesn't want to. } \\ 235 & & \text { (3) } \\ 236 & \text { Pf: } & \text { I'm just going to enjoy myself. } \\ 237 & \text { Am: } & \text { and one who doesn't feel good at home with his family } \\ 238 & \text { some: } & \text { L L ((laughs)) } \\ 239 & \text { Am: } & \text { Lif there are problems with the family. do you hear me? (2) we have a } \\ 240 & & \text { hard time with that in Italy. (2) do you hear me [Kf's name]? } \\ 241 & \text { Kf: } & \text { no } \\ 242 & \text { Am: } & \text { you'll probably be thirty five years old before you understand that. } \\ 243 & \text { STf: } & \end{array}$

\footnotetext{
${ }^{6}$ Krappmann's (2005) four categories of identity-promoting capabilities are role distance, role acceptance and empathy, ambiguity tolerance, and defence mechanisms, also including identity portrayal.

${ }^{7}$ Fantasy is also described as a defence mechanism in Zastrow (2011, p. 148).
} 
International Journal of Child, Youth and Family Studies (2018) 9(2): 61-85

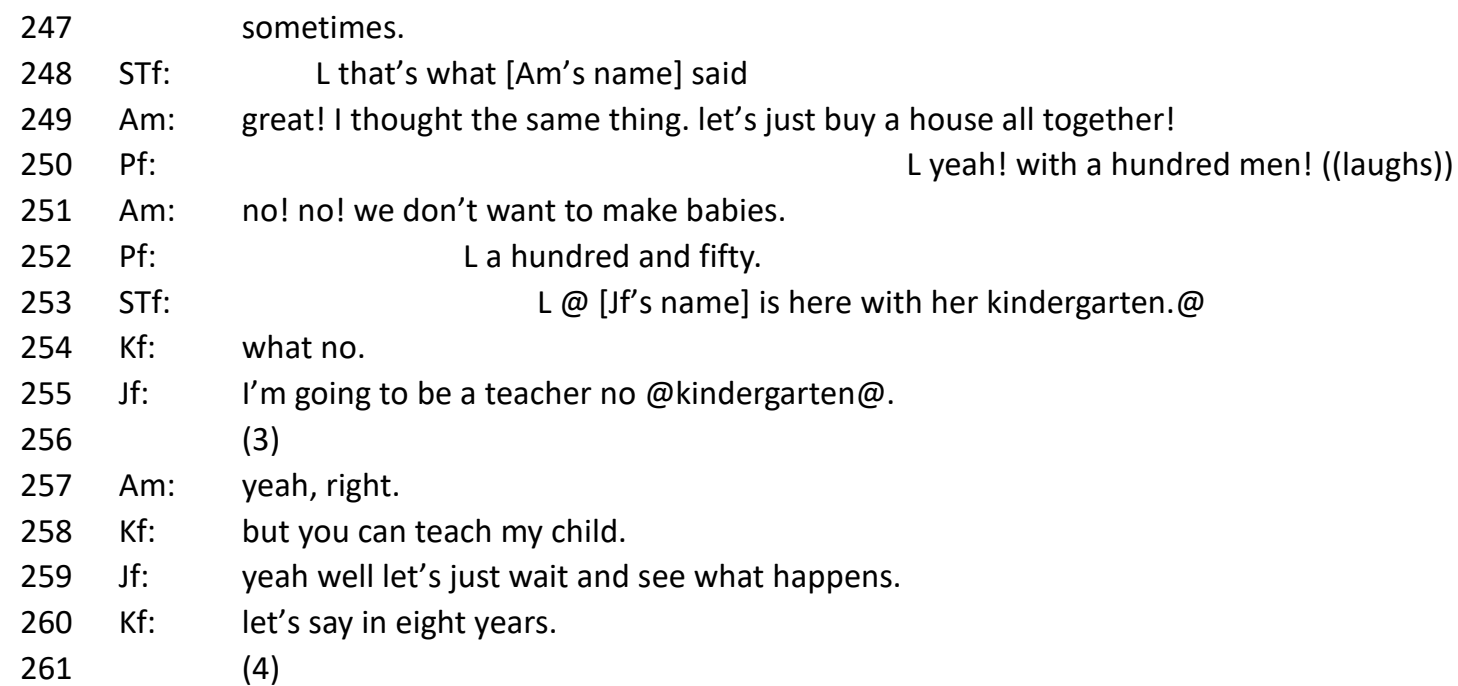

In lines 703 to 721 , another example for the group-based equivalent for a defence mechanism was found, in which the group searches for a way out of the town where the institution is located, "into the universe" so they can find a place "away from everything normal, to live on the moon". Here is also an example of the group choosing fantasy over discussion of realistic possibilities for action.

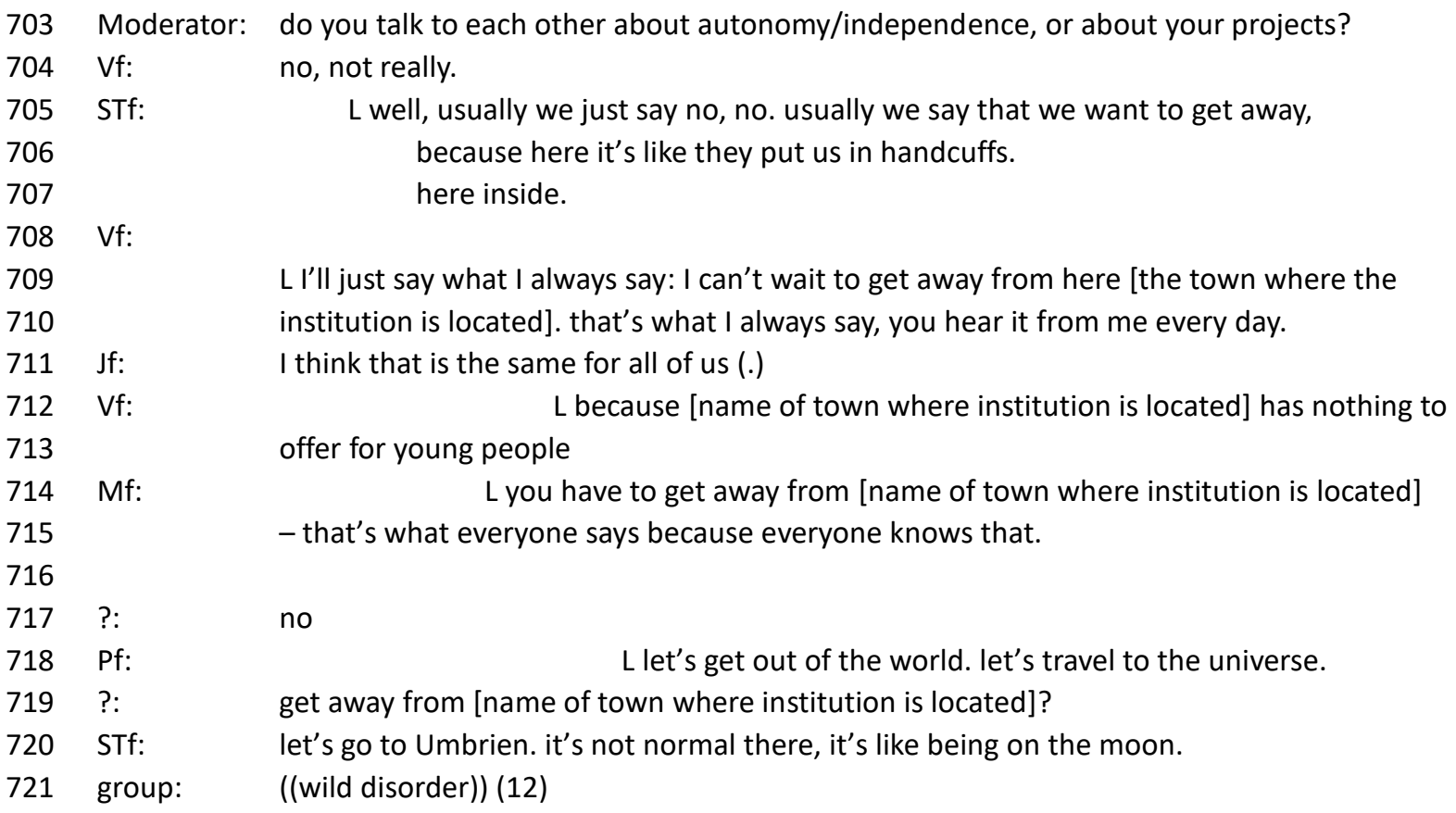

\section{Recurring Patterns of Communicative Action in the SILVESTER Group}

Whereas the XMAS group used irony and self-debasement as well as self -aggrandizement in their communicative action concerning an imposed framework, and the OSTERN group neutralized an uncomfortable topic through fantasy and positive thinking, the SILVESTER group 
repeatedly used ritualized conclusion, normalization, and regression as their preferred tools. Examples of the usage of these types of communicative action have been included below.

In lines 28 to 41, after finding themselves in disagreement over the sense (or senselessness) of the topic under discussion, many of the group members chose a ritualized conclusion by expressing "humpf" as a reaction. This type of ritualized conclusion was repeated later on in the discussion as group members emitted words such as "Bah!"”, clucked like chickens, and made similar animal noises. Przyborski (2004) asserted that ritualized conclusion prohibits contradictory reference points from being expressed. This action, when containing performative elements, can be very impressive (p. 74). The SILVESTER group preferred to use performative, ritualized conclusions to end a contentious discussion or to shift reference points when there didn't seem to be a consensus among the group members. In the course of the following discussion, performative aspects take on a more regressive character when they are examined using the psychoanalytical definition of defence mechanisms as a reference.

The following situation begins with Om asking the group what it means to be pro and contra something. Dm repeats the question.

\begin{tabular}{|c|c|c|}
\hline 28 & Dm: & L what is pro and contra of a subject! \\
\hline 29 & Af: & $\mathrm{L}$ against something \\
\hline 30 & Dm: & what is bad on a topic. \\
\hline 31 & $\mathrm{Nm}:$ & ( ) advantages and disadvantages \\
\hline 32 & group: & (.) \\
\hline 33 & Om: & where do you learn that? in third grade (.)? in which (.) subject? \\
\hline 34 & Nm: & german, yeah \\
\hline 35 & Af: & german \\
\hline 36 & Dm: & but that is not the topic right now. (.) yes \\
\hline 37 & group: & (6) \\
\hline 38 & ?: & humpf \\
\hline 39 & ?: & humpf \\
\hline 40 & ?: & humpf ((again three times from someone, the last two times from Cf and Om)) \\
\hline 41 & Dm: & yeah, topic, no humpf. humpf is not a topic. (.) \\
\hline
\end{tabular}

In lines 142 to 159 while further discussing the present topic (though not the official topic), the group became loud and expressive, which would seem to indicate an important phase. Following a dispute over who must learn to be self-reliant or independent, normalizing statements were expressed, such as, "Everyone must learn to be autonomous", and, "Everyone is here to learn to be autonomous". By the term "normalizing", I mean that the principle that everyone must learn to be independent was transformed into a general rule to be followed. Normalizing can also be found in lines 803 to 810 concerning the topic "assisted living", as well as in lines 252 to 272 , indicating that normalizing is a pattern of action repeatedly used by the SILVESTER group.

142 Af: $\quad$ but there are lots of people in this place who ${ }^{\circ}$ need to learn how to be autonomous, 143 not just. him ${ }^{\circ}$

144 
International Journal of Child, Youth and Family Studies (2018) 9(2): 61-85

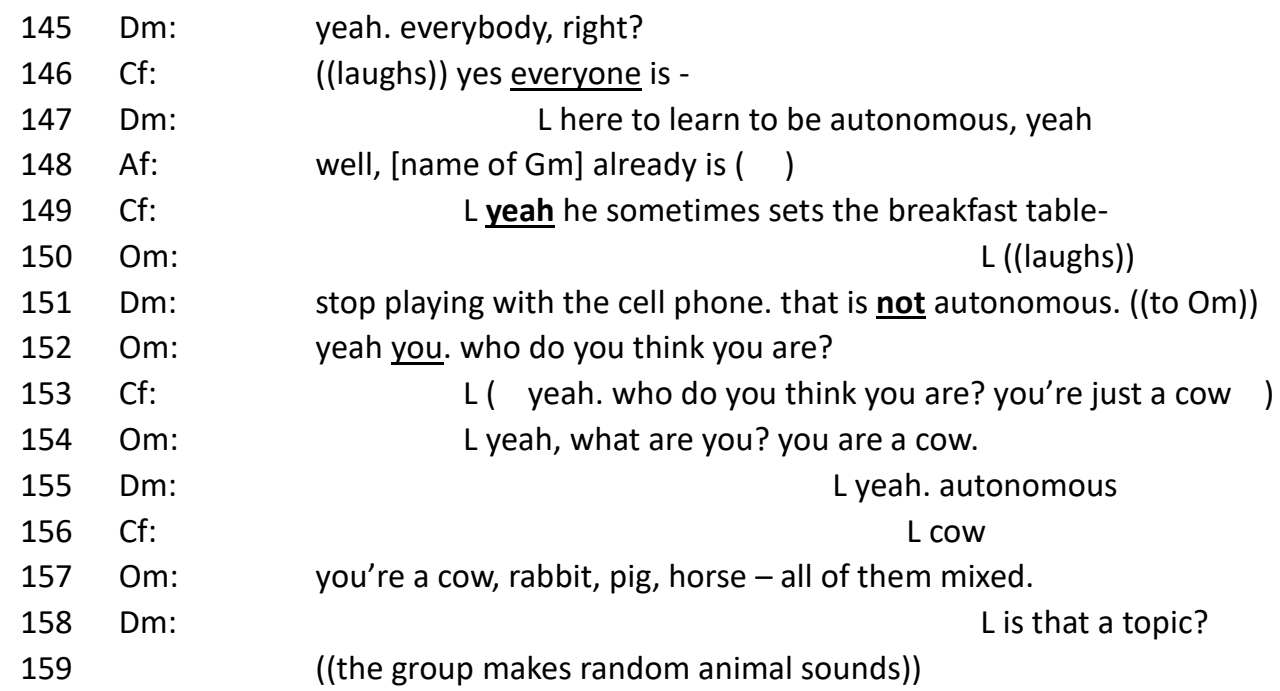

In lines 803 to 810 , the topic autonomy in assisted living was described using phrases such as "everyone must" and "whoever hasn't yet ... learns then". Living in the institution, learning how to be independent, and the learning of autonomy while living in the institution are described as "normal" and "obvious" frameworks of potential interaction, although it is dubious whether the goal of becoming autonomous can be best achieved in such a controlled living situation.

$\begin{array}{lll}803 & \text { Cf: } & \text { yes, you really must with the ( ) } \\ 804 & \text { Af: } & \text { so - anyone who's ((laughs)) not yet autonomous learns how to be autonomous when } \\ 805 & & \text { she/he must do everything by her/himself. } \\ 806 & \mathrm{Nm}: & \text { L ( ) I went to do my kitchen chores and then } \\ 807 & \text { Cf: } & \text { shopping } \\ 808 & \text { Af: } & \text { L shopping, yeah you learn to shop with the care-giver, but (.) } \\ 809 & \text { Cf: } & \text { you also learn how to solve problems by yourself }\end{array}$

In lines 259 to 267, the phrases "everyone knows", "everyone should", and so on serve the function of normalizing, representing the norm in relation to the context. Similarly, "everyone does" and "no one does" imply a moral stance on the topic of autonomy in the institution.

\begin{tabular}{|c|c|c|c|}
\hline 259 & Om & L autonomy & \\
\hline 260 & & 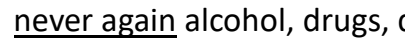 & king (.) everything ( ) \\
\hline 261 & Cf: & & L yeah. e::veryone knows \\
\hline 262 & & what she/he does & \\
\hline 263 & & ((noise)) & \\
\hline 264 & Cf: & and everyone is responsible & \\
\hline 265 & Dm: & $\mathrm{L}$ & ) for what one does \\
\hline 266 & Af: & \multicolumn{2}{|r|}{ L everyone should know where the borderline is. } \\
\hline 267 & Cf: & & L yeah. right. (.) \\
\hline
\end{tabular}


Regression is described in psychoanalysis as a defence mechanism that helps one to master undesirable experiences. It is impossible to judge objectively if a type of behaviour is a defence mechanism or simply a creative construct; the same behaviour can be interpreted one way or the other depending upon the professional context. The childish behaviour of making silly noises can be seen as a regression by the SILVESTER group that, by demonstrating unity, helped to resolve a discord in the group in relation to both the discussion topic and the compulsory character of the discussion setting.

$\begin{array}{llll}647 & \text { Moderator: } & \text { is this somehow connected to autonomy or what? } \\ 648 & \text { group: } & \text { ((the group members all say "baah")) (15) } \\ 649 & \text { Cf: } & \text { de be } \\ 650 & \text { Om: } & \text { (You see, this is difficult for me. debe) } \\ 651 & \text { Cf: } & \text { money money money } \\ 652 & \text { Om: } & \text { mmmm mania mania mania } \\ 653 & \text { Dm: } & \text { gack gack gack gack } \\ 654 & \text { Cf: } & \text { moo } \\ 655 & \text { Om: } & \text { We are wild animals! a wild tiger: meow } \\ 656 & \text { group: } & \text { ((laughs)) } \\ 657 & \text { Cf: } & \text { you want me to punch you? } \\ 658 & \text { Dm: } & \text { ((makes a sound like a horse)) } \\ 659 & \text { Cf: } & \text { ((laughs)) you're a cow } \\ 660 & \text { Dm: } & \text { does this sound like a cow? no, a pig. a pot-bellied pig. } \\ 661 & \text { Om: } & \\ 662 & & \text { ((more animal noises are made and commented upon)) }\end{array}$

Lines 856 to 870 end the discussion:

\begin{tabular}{lll}
856 & Moderator & \multicolumn{2}{l}{ stay here please. now we'll ah now l'll ah...I have something to..., should we, has anyone } \\
857 & & \multicolumn{2}{c}{ anything else to say? } \\
858 & group members simultaneously - no \\
859 & Moderator & well then \\
860 & Dm: & yeah. baah yes baah \\
861 & group: & ((many group members simultaneously - baah)) \\
862 & Moderator & has anyone got anything else \\
863 & group: & ((many group members simultaneously - baah)) \\
864 & Moderator & ((laughs)) ok well then \\
865 & group: & ((many group members simultaneously - baah)) \\
866 & Moderator & I've got a few questions for you \\
867 & group: & ((many group members simultaneously - baah)) \\
868 & Cf: & be quiet!!! \\
869 & Moderator: & today you can all do this by yourselves, here are the papers \\
870 & group: & ((many group members simultaneously - baah)) (8)
\end{tabular}

After having examined the individual group discussions and viewed their differing and unique discourse tendencies, orientations, and recurring patterns of communicative action, the focus will now be directed to a cross-case comparison. 
International Journal of Child, Youth and Family Studies (2018) 9(2): 61-85

\section{Sociogenetic Typification and Comparative Analysis}

\section{Group XMAS}

Group XMAS consisted of four male and two female youth ranging in age from 16 to 18 years, with $50 \%$ from the local area according to their birthplace. XMAS formed the most inhomogeneous group in relation to geographic, cultural, and spoken language backgrounds, and the most homogeneous group in relation to their age-span of 2 years. Their recurrent patterns of communicative action in reference to imposed framework conditions were irony and selfdebasement as well as self-aggrandizement. The paradox that goes along with the institutional demand that they ought to want to be autonomous, and the shared perception of being processed in the institution, was expressed, even performed, through creative means and caricatured, but partly also taken on as a possible orientation and form of social action. Youth-specific topics that were addressed in all groups, like sexuality and sexual orientation and identity, were discussed extensively in this group and were negotiated on the basis of gender roles. Different real-life chances were discussed in connection to gender roles and assigned to them. The topics cigarettes, alcohol, and drugs - means of addiction - also took some time in the discussion, which ranged from a drug-death scenario to the "after-work beer". Money was addressed with the question of how to afford to rent a house or apartment. The negative orientation of ending up under the bridge was addressed twice in this group: first, as a form of radical self-sufficiency that could take place only outside the institution, where one pays for oneself, and if one sleeps under the bridge then one sleeps under the bridge; and second, ironically transformed into self-determined action to walk onto the (their own) bridge all alone after struggles with flatmates. XMAS was the only group where every member of the group participated in the discussion. The most involving and intense of the group discussions, it lasted over one and a half hours, and this group gave positive feedback to the setting and method of group discussion. They seemed to enjoy talking to each other about a defined topic.

\section{Group OSTERN}

Group OSTERN consisted of two male and six female youth ranging in age from 14 to 18 years, with $62.5 \%$ from the local area according to their birthplace. OSTERN was the only group with a female majority, and the only one in which most members had an Italian language background. There were two people who spoke little during the discussion, a young man from Germany and a young woman from South Tyrol. When group members participate only minimally in the discussion it is not clear whether they agree or disagree with the organization and meaning of the group's discourse. As it is integral to the documentary method of interpretation to focus on group patterns, it is not possible to address single participants in group discussions directly and ask for their comments or opinions. The OSTERN group circumvented some topics; a recurrent pattern of communicative action in order to manage imposed framework conditions and the paradox was the neutralizing of an uncomfortable topic through fantasy and positive thinking. The orientation frame in that group was an ambivalence between wanting to leave the group and fearing to be abandoned. The idea of autonomy as total freedom outweighed the simultaneously held idea 
International Journal of Child, Youth and Family Studies (2018) 9(2): 61-85

in which taking responsibility for oneself was emphasized in regard to autonomy. The group perceived that it would be impossible to make a living (be financially autonomous) in an "Italy of crisis". The topic of money was discussed extensively, including the prices of different things and how to afford them, possible ways to make money, and the legal prohibition of child labour, which means that young people are not allowed to take on a job before the age of 16. That was seen by the group as a barrier to earning money. Two of the youth-specific topics that were addressed in all groups, sexuality and identity, were used in this group as an alternative discussion option, which was seen as more attractive than the imposed topic of autonomy. The group mentioned that sexuality would have been a more congenial topic to talk about, and that "to be able to have sex, whenever one wants" was seen as an expression of freedom from institutional control. Sexual orientation and gender roles were not discussed; identity was discussed in relation to the TV series Supernatural, and specifically the character and look of the actors in that series. In contrast to the XMAS group, the OSTERN group did not make a connection to real-life chances in the future. The topics of cigarettes, alcohol, and drugs - means of addiction - were discussed in relation to the price of cigarettes and in relation to beer as a potential trouble-maker or problem-solver. The issue of drinking was connected to the story of the former group member who became homeless. His story also raised the issues of not being able to make a living because life is too expensive in Italy even when people have jobs, and of not being supported any longer by the institution, even after living in it for years. This also led to a discussion of the negative orientation - shared by all the groups - to end up under the bridge or on the street.

\section{Group SILVESTER}

Group SILVESTER consisted of four male and two female youth ranging in age from 12 to 19 years, with $83 \%$ from the local area according to their birthplace. SILVESTER formed the most homogeneous group in relation to geographic, cultural, and spoken language backgrounds, and the most inhomogeneous group in relation to their age-span of 7 years. This group used only German (except for some swear words in Italian). According to group dynamics it seemed to be the youngest group member who had the greatest power. Their recurrent patterns of communicative action in reference to imposed framework conditions were normalizing and ritual actions that acted as a form of regression. One distinctive trait of the SILVESTER group was the use of ritualized actions (shared singing and emitting of imitative animal sounds, and the collective transfer of topics to an animal analogy). In confrontation with the paradoxical demand by the institution that "residents should desire to be independent", this group reacted by normalizing or creating norms on the one hand, and utilizing ritualistic conclusion, which can also display a regressive character, on the other hand. These reactions occur predominantly in cases where insurmountable inconsistencies in the group members' orientations exist.

A major point in the orientation framework of the group was support and guidance in the achievement of autonomy through the involvement of both parents and care-givers. The

participants felt that this involvement was intended to make the transition to autonomous living easier for them. Regarding the topic of money, the participants agreed that one must learn how to 
International Journal of Child, Youth and Family Studies (2018) 9(2): 61-85

deal with money and should not spend it all at once, but rather make a smart plan and spend carefully.

Table 2 Summary of Communicative Action Patterns Utilized by Discussion Groups in Reaction to Imposed Framework Conditions

\begin{tabular}{|c|c|c|}
\hline Group characteristics & $\begin{array}{l}\text { Group-specific pattern } \\
\text { of communication }\end{array}$ & Communicative actions: Examples \\
\hline \multicolumn{3}{|l|}{ "XMAS" } \\
\hline $\begin{array}{l}\text { - the most inhomogeneous } \\
\text { group in relation to } \\
\text { geographic, cultural, and } \\
\text { spoken language } \\
\text { backgrounds }\end{array}$ & $\begin{array}{l}\text { ironische Selbstentwertung } \\
\text { (ironic self-debasement) }\end{array}$ & $\begin{array}{l}\text { "I am the second Karin" } \\
\text { (meaning I am the second piece of assembly-line } \\
\text { autonomy production in the institution - and } \\
\text { function suboptimally, like Karin) }\end{array}$ \\
\hline $\begin{array}{l}\text { - the most homogeneous } \\
\text { group in relation to age- } \\
\text { span ( } 2 \text { years) } \\
\text { - male majority }\end{array}$ & $\begin{array}{l}\text { Selbst-Überhöhung } \\
\text { (self-aggrandizement) }\end{array}$ & $\begin{array}{l}\text { "That's how I really wanna end up, that's cool" } \\
\text { ("heroic" end-time scenario in which a young man } \\
\text { orchestrated a drug-death fantasy, obsessed with } \\
\text { his own effect, and reduced everyone else to } \\
\text { passive spectators) }\end{array}$ \\
\hline
\end{tabular}

\footnotetext{
“OSTERN"

- a relatively homogeneous group in relation to geographic, cultural, and spoken language backgrounds

- a relatively homogeneous group in relation to agespan (4 years)

- the only group with a female majority

\section{Fantasie}

(neutralizing of an uncomfortable topic through fantasy)

positiv Denken (neutralizing of an uncomfortable topic through positive thinking)

"Let's just buy a house all together!"

"Yeah! With a hundred men!"

(after a passage in which the "crisis in Italy" was discussed, and that it would be impossible to afford a flat even with a thousand euro wage, and therefore one would be forced to live with family, and if there are problems in the family then it's a real problem.)

"Hey, come on - look what you have got us talking about!"

(a former colleague in the institution who started drinking and ended up homeless)

"Let's talk about [Kf's name] fingernails."

\section{"SILVESTER"}

- the most homogeneous group in relation to geographic, cultural, and spoken language backgrounds

- the most inhomogeneous group in relation to age-span (7 years)

- male majority

\section{Normalisierung}

(normalization)

Regression

(using group rituals in a regressive manner)

"Everyone is here to learn to be autonomous."

"Everyone is responsible" (for his own behaviour)

"We are wild animals"

[and that's performed in the group]

"Money money money ..."

"Mmmm mania mania mania..."

"Gack gack gack gack..."

"Meh..." (sounds like cows)
} 
International Journal of Child, Youth and Family Studies (2018) 9(2): 61-85

The subject areas of cigarettes, alcohol, and drugs - means of addiction - were dealt with in diverse contexts: when the camera showed Am lighting his cigarette during a discussion; when the group members discussed how old one should be to drink and smoke and which colleagues were smokers; in relation to autonomy - how can one take care of oneself, to be responsible for oneself by "knowing what to do"; and finally in the acceptance of the obligation to protect oneself through abstinence from drugs and alcohol.

The topics of sex and sexual orientation and identity were first broached jokingly in respect to sexual organs (testicles and ovaries) and then in relation to the question, "Who is like which animal and which animal is better - for instance a rooster or a 'staller" ? Further discussion involved sexualized language clearly used to create a borderline between the adults in the context and the peer-context ("fuck you hard"). The group also sang a song together with sexual content (including the words "naked" and "fucking"). There was also a metadiscourse about one group member's presumed lesbian relationship.

The topic of identity was considered when Om, the youngest in the group, presented a story of a beggar living in a garbage container. The group began to speak of how it would feel to be forced into living like that. The story was initially rejected by the group, because it didn't have to do with the topic at hand, but then they did discuss it. In fact, it represents the negative orientation across groups, the image of "ending up under the bridge". The beggar, given the name Bippo, had to survive under a bridge at the bottom of a garbage can as well as he could. When one of the group members ridiculed the beggar, the other members wondered how that member himself would feel if his own mother threw him under the bridge into the garbage can. Although not all members agreed, the group then found a rational reason why a person would sleep in the garbage can: it was better than dying of exposure. However, one group member said he would prefer death.

\section{Conclusion}

The analysis of group discussions based on the documentary method of interpretation revealed power-based hierarchical arrangements in the care setting through the detection of imposed framework conditions in the text. The initial question asked by the moderator in the group discussions reproduced the care setting by asking the young people exclusively about autonomy, which, as the main educational aim of the institution, engenders a demand that the young people ought to want to be autonomous. This creates a paradoxical situation in relation to the aim of autonomy, with which the young people must come to terms. In managing the paradoxical situation, and in reacting to the imposed framework conditions in the discussion, the participants utilized group-specific patterns of communicative action, which were reconstructed in the analysis. A compilation of the typology of the patterns of communicative action used by those in group care in residential homes would need a multitude of other cases for comparison. Different groups in

\footnotetext{
${ }^{8}$ In the area where the research took place, "staller" is a slang term for a peasant with out-of-date views.
} 
residential homes, and also reference groups in other institutions like schools, where similar but divergent structures and paradoxical arrangements might exist, could be included in investigations.

Carers must become aware that autonomy as the social pedagogical objective and learning outcome of youth in group care cannot be pursued directly and without obstacles. Ideally, those caring for young people will agree to an open-ended process, keeping autonomy in mind and accepting existing struggles for autonomy. The patterns identified in this study, as well as additional patterns, could be identified as a specific competence of youth residing in group care residential homes and could perhaps become a transferrable skill for care-leaving transition and in life after care. Empowerment of the care leaver should include articulation and recognition of their experiences and their knowledge, and should further support them in taking a role in the political discourse surrounding the professional care sector. The international youth assembly, which took place in Vienna in 2016 before and during the 33rd FICE International World Congress, can be seen as an important step in the development of a political voice for care leavers. Fifty-three young people from 15 countries, who either lived in care at the time or had recently lived in care, presented their concrete suggestions, as experts through experience, for the improvement of the professional and political context of child welfare (Koch, 2016, p. 304). Their 10 statements included, "All care leavers should be supported in becoming aware of and acknowledging their own potential, so that they are able to grasp the chance to develop it further" (Koch, 2016, p. 305). That the youth are capable of acting within the paradoxical arrangement of institutional care has been demonstrated in this study. An understanding of the influence of the paradox is necessary if we are to improve outcomes of the social pedagogical treatment model in residential care settings and thus improve the life chances of residential care alumni and the experience of leaving care for young adults. 
International Journal of Child, Youth and Family Studies (2018) 9(2): 61-85

\section{References}

Albus, S., Greschke, H., Klingler, B., Messmer, H., Micheel, H.-G., Otto, H.-U., \& Polutta, A. (2010). Wirkungsorientierte Jugendhilfe: Abschlussbericht der Evaluation des

Bundesprogramms ,,Qualifizierung der Hilfen zur Erziehung durch wirkungs $\neg$ orientierte Ausgestaltung der Leistungs-, Entgelt- und Qualitätsvereinbarungen nach §§ 78a ff SGB VIII" [Impact-oriented youth welfare: Final report of the evaluation of the federal model program "Qualification of assistance to education through impact-oriented design of the performance, remuneration and quality agreements according to $\S \S 78$ a ff SGB VIII']. Münster, Germany: Waxmann.

Barbarotto, M., \& Mineo, F. (Eds.). (2012). Report on abandonment \& care leavers. Supporting life after institutional care. Milano, Italy: Ancora.

Baur, D., Finkel, M., Hamberger, M., Kühn, A. D., \& Thiersch, H. (1998). Leistungen und Grenzen von Heimerziehung: Ergebnisse einer Evaluationsstudie stationärer und teilstationärer Erziehungshilfen (Schriftenreihe des Bundesministeriums für Familie, Senioren, Frauen und Jugend 170). Stuttgart, Germany: Kohlhammer.

Bohnsack, R. (2003) Rekonstruktive Sozialforschung. Einführung in qualitative Methoden [Reconstructive social research. Introduction to qualitative methods] (5th ed.). Opladen, Germany: Leske + Budrich.

Bohnsack, R. (2014). Documentary method. In U. Flick (Ed.), The Sage handbook of qualitative data analysis (pp 217-233). Thousand Oaks, CA: Sage.

Bundesministerium für Familie, Senioren, Frauen und Jugend (Eds.). (2002). Effekte erzieherischer Hilfen und ihre Hintergründe [Effects of educational aids and their backgrounds] (Schriftenreihe des Bundesministeriums für Familie, Senioren, Frauen und Jugend 219). Stuttgart, Germany: Kohlhammer.

del Valle, J. F. (2014). Children in state care. In A. Ben-Arieh, Ferran Casas, Ivar Frønes, Jill E. Korbin (Eds.), Handbook of child well-being (pp 2945-2963). Dordrecht, Netherlands: Springer Science+Business Media. doi:10.1007/978-90-481-9063-8_119

Ehlich, K., \& Rehbein, J. (1979). Sprachliche Handlungsmuster [Linguistic patterns of action]. In H.-G. Soeffner (Ed.), Interpretative Verfahren in den Sozial- und Textwissenschaften [Interpretative procedures in the social and textual sciences] (pp. 243-274). Stuttgart, Germany: Metzler.

Harder, A. T., Köngeter, S., Zeller, M., Knorth, E. J., \& Knot-Dickscheit, J. (2011). Instruments for research on transition: Applied methods and approaches for exploring the transition of young care leavers to adulthood. Children and Youth Services Review, 33(12), 2431-2441. doi:10.1016/j.childyouth.2011.08.017 
International Journal of Child, Youth and Family Studies (2018) 9(2): 61-85

Koch, J. (2016). FICE Award und Jugendkongress auf dem 33 [33rd FICE Award and Youth Congress]. FICE Kongress in Wien. Forum Erziehungshilfen, 22(5), 304-305.

Krappmann, L. (2005). Soziologische Dimensionen der Identität: Strukturelle Bedingungen für die Teilnahme an Interaktionsprozessen [Sociological dimensions of identity: Structural conditions for participation in interaction processes] (10th ed.). Stuttgart, Germany: KlettCotta.

Laplanche, J., \& Pontalis, J.-B. (1999). Das Vokabular der Psychoanalyse [Vocabulary of psychoanalysis] (15th ed.). Frankfurt am Main, Germany: Suhrkamp.

Lerch, V., \& Stein, M. (Eds.). (2010). Ageing out of care. From care to adulthood in European and Central Asian societies. Innsbruck, Austria: SOS Children's Villages International.

Macsenaere, M., \& Knab, E. (2004). Evaluationsstudie erzieherischer Hilfen (EVAS). Eine Einfuihrung [Evaluation of educational aids (EVAS). An introduction]. Freiburg, Germany: Lambertus.

Munro, E. R., Stein, M., \& Ward, H. (2005). Comparing how different social, political and legal frameworks support or inhibit transitions from public care to independence in Europe, Israel, Canada and United States. International Journal of Child and Family Welfare, 8(4), 191-202.

Nohl, A. M. (2017) Interview und Dokumentarische Methode: Anleitungen für die Forschungspraxis [Interview and documentary method: Guidance for research practice] (5th ed.). Wiesbaden, Germany: Springer VS.

Planungsgruppe Petra. (1988). Was leistet Heimerziehung. Ergebnisse einer empirischen Untersuchung [What does home education do? Results of an empirical study]. Regensburg, Germany: Walhalla u. Praetoria.

Przyborski, A. (2004). Gesprächsanalyse und dokumentarische Methode: Qualitative Auswertung von Gesprächen, Gruppendiskussionen und anderen Diskursen [Interview analysis and documentary method: Qualitative evaluation of conversations, group discussions and other discourses]. Wiesbaden, Germany: VS Verlag für Sozialwissenschaften.

Stein, M. (2006). Research review: Young people leaving care. Child and Family Social Work, 11(3), 273-279. doi:10.1111/j.1365-2206.2006.00439.x

Stein, M., \& Munro, E. R. (Eds.). (2008). Young people's transitions from care to adulthood: International research and practice. London, UK: Jessica Kingsley. 
International Journal of Child, Youth and Family Studies (2018) 9(2): 61-85

Tajfel, H., \& Turner, J. C. (1986). The social identity theory of inter-group behavior. In L. W. Austin \& S. Worchel (Eds.), Psychology of Intergroup Relations (pp. 7-24). Chicago, IL: Nelson-Hall.

Tänzler, B., \& Luckner, S. (2012). Kinderheim statt Kinderzimmer. Neun Leben danach [Children's home instead of children's room. Nine lives after]. Zürich, Switzerland: Urs Bernet.

Wenninger, G. (2000). Abwehrmechanismen [Defence mechanisms]. Lexikon der Psychologie [Lexicon of psychology]. Heidelberg, Germany: Spektrum Akademischer. Retrieved from http://www.spektrum.de/lexikon/psychologie/abwehrmechanismen/112

Wolf, K. (2002). Erziehung zur Selbstständigkeit in Familie und Heim [Education for selfemployment in family and home]. Münster, Germany: Votum.

Zastrow, C. H. (2011). Social work with groups: A comprehensive worktext (8th ed.; Brooks/Cole Empowerment Series). Boston, MA: Wadsworth Cengage Learning. 